Current Issues of Education and Science, 2021

DOI: $\underline{\text { https://doi.org/10.26697/9786177089147.2021.03 }}$

\title{
Modern Features and Trends in the Development of the Architectural Education System
}

\author{
Larysa S. MARTYSHOVA ${ }^{1}$
}

${ }^{1}$ O. M. Beketov National University of Urban Economy in Kharkiv, Ukraine

\section{Corresponding Author Details}

Larysa S. MARTYSHOVA, larymarkaz@gmail.com

Received: 01.10.2021; Accepted: 29.10.2021; Published: 17.12.2021

\section{Brief Summary}

Background: Introduction discusses the core global contemporary transformations that embrace all the areas from creating material world objects to the processes of environmental changes overall. These processes involve all the aspects of human life: philosophy, methodology, culture, science, education etc.

The aim of the study: To find the contemporary features of training architects and the trends in architectural creativity development, as well as to establish their interaction with the development of the current approaches in architectural education, under the conditions of changeable socioeconomic requirements and technological capacities.

Methods: The research methods are determined by those modern architecture is focused on, namely, the system worldview, model thinking, ability to generalize and manage. Methodological and theoretical bases of the study are the general scientific approaches and principles of dialectical development; system and interdisciplinary approach.

Results: The research outcomes show that the potential of contemporary architectural creativity as an interdisciplinary area is based on the holistic perception of the environment (with its uniqueness, originality and specificity) and, in turn, on the complete architectural education and architect's talent. 
Conclusions: The conclusion identifies the main contemporary features and trends in the development of the architectural education system: the role of the educational structure in the system of architectural education and the architectural creativity practice is built on such grounds as the continuity of cultural values, modernization of educational processes, keeping national traditions, learning international trends; the interdisciplinary approach becomes the key instrument and method in the architectural creativity and education; the architecture relies equally on engineering and humanitarian aspects.

\section{Keywords:}

architecture, architect, architectural education, architectural creativity, environment, integrity, interdisciplinary.

\section{Background:}

In today's unified world there is an issue of developing creative abilities and creative potential of a personality at all educational cycles (from pre-schooling to higher education). Therewith, the fundamental changes in the long-standing customs and traditions lead to the emergence of a new epoch, new civilization, and, naturally, to the establishment of the new criteria of architectural education. Still, universal and timeless values and human psychology are to be kept, since they serve as the basis and reality of architect's life and creativity (Czyikov, 2008). Overall, creativity, regarded as making unique tangible and intangible values, is not subject to a well-established scheme or an algorithm. People always admire the creativity of the great masters but even the most prominent figures cannot reproduce their creative works accurately, because the creative process is similar to the river flowing, where every moment is unique and different from the others.

Architectural education is a special branch of education that aims to train and shape an architect, who creates a new environment aesthetically and skillfully. An architect is then not a merely thinking qualified specialist but an integral, harmonious type of personality capable of seeing and perceiving as well as of creating the environment as a unified whole of interrelated elements, and even of foreseeing the development of this whole - the multifaceted world of human activity. The environment is not just the habitat (place of functioning) for a person, but an artwork, which is distinct and original from the natural, cultural and socio-historical perspectives. In architect's view, the environment is the integrity, an organized space that continuously surrounds a person, who uses architecture to actively and 
permanently influence the common process of shaping this twofold structure. By creating an artificial environment for human life, architecture affects human psyche in different ways, and the biggest impact is through the visual perception, since human activities are always related with various forms of environment perception (Shubovych, 2005).

UNESCO-UIA Charter for Architectural Education states that "Architecture is a discipline which draws knowledge from the humanities, the social and the physical sciences, technology, environmental sciences, the creative arts and the liberal arts. Architectural education is to ensure the following outcomes: the ability to understand the relations between people and architectural facilities, on the one hand, and between the architect and environment on the other. It is also to provide for the ability to correlate architectural facilities and space with the human scale (Unesco-Uia, 2017).

The problem of the architectural creativity development as the means of architectural thinking is essential in architectural education. In modern conditions the sources of creativity increasingly often include knowledge, scientific and technological innovations, and their applications in education. The knowledge of the world cultural and domestic heritage, the ability to creatively combine it with the contemporary architectural art and solve topical complex social space problems serve the grounds for training a personality with new intellectual and creative thinking. A specific feature of the problem is that to solve it, it is necessary to go beyond the existing knowledge. Continuous information updating in science, technologies, innovations, and education enables to consider that this problem is nearly always an open system for researchers, which inevitably leads to searching for the ways to upgrade theoretical models, philosophical approaches, and worldviews in architectural practice and education.

The aim of the study. To identify contemporary features of training architects and the trends in architectural creativity development, as well as to establish their interaction with the development of the current approaches in architectural education, under the conditions of changeable socioeconomic requirements and technological capacities.

\section{Methods:}

It is impossible to achieve the above aim without knowing and considering fundamental research in the fields of philosophy, natural sciences, and new technologies, where these problems have been studied by scholars, architects, education theorists and practitioners in general and in particular in architectural education. In this respect, the focus is made on the important role of the direct perception of the environment, which is crucial for shaping architect's worldview, and also on the artistic architectural 
creativity and humanitarian education system, which is an integral part of the fundamental professional education.

Methodological and theoretical bases of the research involve general scientific approaches, which can be applied to architecture and architectural education: the laws and principles of dialectical development; the system approach, determined by the social-cultural architectural concepts; and the interdisciplinary approach, which implies the use of the concepts, models and theories from carious areas of theoretical and practical knowledge.

\section{Results:}

The theoretical value of the study is in the opportunity to use its provisions and conclusions in creating generalizing research that rely upon the experience of modern architectural creativity, new architectural thinking and further architectural education development based on the integrative processes in science, education, and practice with the active implementation of innovative technologies.

The practical relevance of the study is in confirming the need for the accumulated experience and modern architectural trends, the need for reforms and improvements of architectural education in the new continuously changeable conditions. The results of the research may be used in the development of the new generation educational programs, the choice of the system and methods of education.

The traditional system of architectural education is oriented on specialized professional training, which implies educational process division into the major (specializing) disciplines and minor (humanitarian). This approach to architect training that distinguishes architecture from the system of "nature - architecture - person", does not provide the holistic concept of architecture, while a person who genetically and instinctively seeks harmony, does not receive the holistic image of the world. As a result, architecture does not reach its main goal - to create the material environment integrity ("second nature") of the surrounding world (Shubovych, 2005). The significance of the architectural education in the process of the contemporary society and environment development overall determines the possibility of not merely uniting various elements in a single organism but also the opportunities of monitoring and finding connections between generations, reflected in architectural space shapes. Thus, architectural education acts as the information environment, responsible for the development of the architectural context of our cities and the environment on the whole through shaping architect's creative personality. Currently, in today's informationally overloaded world, when the production is most often merged with science, and the need to unite the 
scientific training and practical experience has been urgent, the architectural profession requires not only numerous art and technical skills, but also understanding of interrelations among the elements of the profession (Rappaport, 1975). Contemporary research in architecture somehow goes beyond the conventional framework and considers an increasingly broader scope of knowledge from economy to poetics.

Architectural creativity is an interdisciplinary field that represents the unique activity, aiming at the active value-based acquisition and understanding of the worldview image, which depends on social, cultural, religious, political, moral, technological, economic and other conditions, thus uniting humanitarian and engineering aspects (Karmazin \& Kapustin, 2003). The unique experience of the architectural creativity is gradually accumulated, enriching the arsenal of cultural heritage, traditions and types of creation. That way, the range of professional methods, techniques and means is continuously widening, the worldview is changing, and creative thinking is developing. A special trait of the new epoch is the establishment of the structure of the new type of knowledge, where all the areas of human activities: science, education, production, and business, are integrated in the integrated developing system. The world around us is continuously changing along with the benefits and values, landmarks and attitudes. The contemporary understanding of the matter structure and motion claims that the environment is an integrated system and, consequently, the system approach to world learning and transforming is philosophical, specifying the principles of the general connection.

The state of the sociopolitical system, education level, architect's personal professionalism and general cultural background level determine the overall future of the humanity, nations, states and their economies. The trends of the architectural education system development are expressed in multitasking: seeking to balance the need for fast response to processes, the ability to change when making decisions and the importance of principal positions in the matters of knowledge, society, culture, environment, ethics and esthetics. Architecture and architectural creativity in general are expanding their geography, trying to become universal, losing numerous traditional features and specifics. This trend for internationalization implies both new potential потенціал and new, often unprecedented, challenges. Therefore, the need for protecting and conserving architectural heritage is increasing, demanding the provision by the architectural education of the skills and abilities to navigate in the complicated system of the real world connections. For example, UNESCO-UIA Charter for Architectural Education draws attention to the problem of imperfection and incompliance with the dynamics of the architectural education development with the level 
of contemporary international socioeconomic conditions and requirements (Unesco-Uia, 2017).

Architecture has always been reflecting relations between people and the world: with the immediate environment and with the Universe in general, unites the imaginary and functional aspects and is predominantly material and synthesizes seemingly incompatible layers of human culture. Architects have always travelled and sought to work as much as possible in various parts of the world, learning and studying different cultures and traditions, which enormously enriched their worldview and enabled creativity. Owing to the internationalization of education and mobility, the availability of numerous programs and grants, contemporary students and teaching staff have wide opportunities and prospects not only to study but also work or collaborate with prominent experts worldwide. The modern engineering innovations are an excellent tool, especially in the situation of forced isolation (e.g. pandemic), unsurmountable distances or personal factors (e.g., physiological ones). However, for the architectural education it is important to have a tight personal contact with the teacher (mentor), as it has always been. From time immemorial, a person would master the craft, the skills were passed down from person to person, adapting to a specific specialist, therefore, workshops are so highly valued worldwide. The invisible link emerging between a student and a teacher (it includes everything: individuality, intuition, inspiration, courage, passion for the master's personality and willingness to be similar to him, and eventually the aspiration to be a "master (expert)") (Martyshova, 2016).

The modern global educational system is undergoing the period of quality reforms and breakthroughs. This field of life is being completely transformed, and it is anthropocentric, i.e. oriented on people and their needs. The approach, oriented on studying natural and general scientific worldview, used to do research into the complex scientific problems was suggested by Vernadskiy (1977). Architectural creativity is social by nature, because contemporary architecture, being a new material environment does not fit the framework of yesterday's criteria, and the society is continuously setting new requirements to both the form (material qualities), and the content (philosophy, spiritual, cultural-esthetic, social and functional meaning) (Vernadskiy, 1977).

The research showed that the potential of the contemporary architectural creativity as an interdisciplinary area is based on the integrity of perceiving the environment (with its inherent uniqueness and originality) and, in turn, on the completeness of architectural education and architect's talent. A considerable impact on the condition and development of architecture is currently made by the dialectical-methodological approach to 
the problem of interaction among architectural creative practice, architectural education and science, where the crucial factors were the innovative principles of architectural school education, theories, concepts and creative works by the prominent architects of the early 20th century. The contemporary architectural education is at the stage of selecting the system and model of further development in the conditions that rapidly change, which requires transformations in the educational system. For example, over the period of the first two decades of the 21 st century, along with the contemporary trends for the active introduction of scientific and technological developments in all areas of human life, including the practice of architectural creativity, architectural education is lagging behind: relations of the science and practice are being lost and, which is especially important, interdisciplinary links are being lost, though they promote integrated perception, preservation and creation of the environmental integrity.

\section{Conclusions:}

Modern trends in architects' training within the architectural educational system area characterized by the need of the active practical use of the achievements of fundamental and applied sciences, engineering, innovative technologies, cultural development, which, in turn, turn the image of the architecture as a system of fragmented knowledge (elements) into the aspiration to establish integrated environmental knowledge.

The new era in the practice of developing contemporary trends in training architects within the architectural education system has been formed by a number of factors: cultural-historical heritage of architectural schools of the early 20th century and the emergence of new architectural schools, creative associations, training architects, builders, designers and artists. Thus, the modern architectural education is in the sociocultural conditions, which are changing dynamically, and in the process of seeking essential creative trends. The process is based on two main areas: vocational education and humanitarian education.

Along with global quality changes, the contexts and theories, related to national and regional interests are being activated and confirmed as well; the value-based criteria of the national traditions in architectural creativity and education are identified. The observed reflection of international features in national cultures is based on the principles, on the one hand, mutual enrichment and development, on the other - universalization.

According to the modern international requirements and conditions, the role of the educational structure (as the unified model of educationscience-practice) in solving the problems of continuity, consistency, and 
succession in the architectural education system and practice, built on the principles of passing down cultural values, modernization of educational processes, keeping national traditions, learning international trends, has gained significance. While the interdisciplinary approach is becoming an essential tool and method in the practice of architectural creativity and education.

\section{Conflicts of interests:}

The author declares that there is no conflict of interests.

\section{Source of support:}

This research did not receive any outside funding or support.

\section{References}

Czyikov, S. S. (2008). Arhitectura buduschego: osmyslenie i model razvitiya [Architecture of the future: comprehension and model of the development]. Arhitecton: Izvestiya vuzov - Architect: News of Higher Educational Institutions, 2(22). https://archvuz.ru/2008_2/7 [in Russian]

Karmazin, Yu. I., \& Kapustin, P. V. (2003). Gumanizatciya arhitecturnoy deyatelnosti i gumanitarnoye soderzhaniye professionalnogo obrazovaniya [Architectural activity humanisation and humanitarian content of professional education]. Izvestija vysshih uchebnyh zavedenij: Stroitelstvo - Bulletin of higher educational institutions: Construction, 7 ,

$119-125$. https://izvuzstr.sibstrin.ru/uploads/publication/fulltext/7-2003.pdf [in Russian]

Martyshova, L. S. (2016, April 28-29). Gumanitarnaya sostavlyauschaya podgotovki arhitectora [The humanitarian component of the architects training] [Poster presentation]. Modern Problems of Youth Education in Higher Education, Kharkiv, Ukraine. https://eprints.kname.edu.ua/44963/ [in Russian]

Rappaport, A. G. (1975). Proectirovanie bez prototipov [Design without prototypes]. Razrabotka $i$ vnedrenie avtomatizirovannyx system $v$ proectirovanii (teoriya $i$ metodologiya) [Development and implementation of automated systems in design (theory and methodology)]. https://www.prisslaboratory.net.ru/library/library_rappaport_prototype.pdf [in Russian]

Shubovych, S. A. (Ed.). (2005). Gumanitarny kompleks arhitectury. K voprosu o gumanitarnyh issledovaniyah $v$ architecture [Humanitarian complex of architecture. To the issue of humanitarian researches in architecture]. XNAGX. [in Russian] 
Vernadskiy, V. I. (1977) Razmyshleniya natyralista. Nauchnaya mysl kak planetnoe yavlenie. [Reflections of a naturalist. Scientific thought as a planetary phenomenon]. http://www.isaran.ru/bookreader/publication.php?guid=BB9E42F956DA-7238-BAA8-C9A85D26BAB6\&ida $=1 \&$ kod=9 [in Russian] UNESCO-UIA. (2017). Charter for architectural education. (Ed. 20142017). https://www.uiaarchitectes.org/webApi/uploads/ressourcefile/178/charter2017en.pdf

\section{Information about the author:}

Martyshova Larysa Serhiivna - https://orcid.org/0000-0002-2211-3562; $\mathrm{PhD}$ in Architecture, Associate Professor of Urban Planning Department, O. M. Beketov National University of Urban Economy in Kharkiv, Ukraine. Research interests: information-semantic and landscape-compositional problems of the architectural environment spatial structure.

\section{Cite this article as:}

Martyshova, L. S. (2021). Modern features and trends in the development of the architectural education system. In Yu. B. Melnyk, \& L. M. Georgieva (Eds.), Current Issues of Education and Science. 9th International Conference, CIES-2021, Riga, Latvia - Kharkiv, Ukraine, November 10-13, 2021, Conference proceedings (pp. 16-24). KRPOCH. https://doi.org/10.26697/9786177089147.2021.03

\section{Copyright information:}
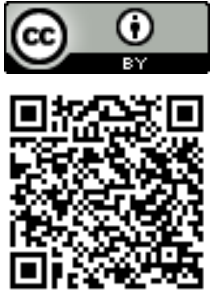

The published paper are licensed under a Creative Commons "Attribution" 4.0 Worldwide

The electronic version of this article is complete. Full or partial reproduction of article is allowed, citing to the source, author(s) and DOI. An electronic copy of the Conference proceedings in open access is available via the KRPOCH Publishing website https://publisher.culturehealth.org 